\title{
THE ROLE OF IMPRISONMENT AND CENSORSHIP IN THE INTERNATIONAL SUCCESS \\ OF PRAMOEDYA ANANTA TOER'S BURU QUARTET NOVELS
}

\author{
Yani Susanti \\ Graduate Student of Creative Writing, Faculty of Social Sciences and Humanities, \\ London Metropolitan University \\ 166-220 Holloway Road, London N7 8DB \\ yani.susanti@gmail.com
}

\begin{abstract}
Imprisonment and censorship that is meant to silence Pramoedya Ananta Toer and his books did not succeed. On the contrary, they only help popularize Pramoedya Ananta Toer's Buru Quartet novels in the international market. Through some library researches, this article analyzed the purpose of imprisonment, the impacts it has on Pramoedya Ananta Toer's career in the literary world and related them to Pierre Bourdieu's concept of capital. It is concluded that this triumph over imprisonment and censorship owes its success to Pramoedya Ananta Toer's strong connections with the people that matter in his lifetime.
\end{abstract}

Keywords: imprisonment, censorship, Pramoedya Ananta Toer, capital, Pierre Bourdieu

\begin{abstract}
ABSTRAK
Pemenjaraan dan pembredelan yang bertujuan untuk membungkam Pramoedya Ananta Toer dan bukunya tidak berhasil. Sebaliknya, hal ini membantu memopulerkan keempat novel Tetralogi berjudul Buru di pasar internasional. Melalui kajian pustaka, artikel menganalisis tujuan pemenjaraan, dampak pemenjaraan terhadap karier Pramoedya Ananta Toer dalam dunia kesusastraan dan menghubungkannya dengan konsep kapital Pierre Bourdieu. Disimpulkan bahwa kemenangan atas usaha pemenjaraan dan pembredelan ini berhasil berkat hubungan kuat Pramoedya Ananta Toer dengan orang-orang yang berpengaruh besar semasa hidupnya.
\end{abstract}

Kata kunci: pemenjaraan, pembredelan, Pramoedya Ananta Toer, kapital, Pierre Bourdieu 


\section{INTRODUCTION}

Throughout history, writers who are critical, influential and vocal in opposing authority may be found suffering from imprisonment and exile. In many cases, their works are banned or even burned. These vile actions are mostly meant to silence these writers, to ensure that their words never get to see the light of day. Yet, these muffling efforts have not always been successful. In some cases, they even help popularize these writers' works. Using Pierre Bourdieu's concept of capital to support the analysis, this paper intends to prove that acts of silencing writers, such as imprisonment and censorship can be used to boost the success of Pramoedya Ananta Toer's Buru Quartet novels to penetrate the international market.

\section{METHOD}

This article presented library research that found out the theories of Pierre Bourdieue's Capital and Richard Jenkins to explore the purpose of Pram's imprisonment, the significances of his books, and to prove the triumph of Pram's capital over imprisonment and censorship.

\section{DISCUSSION}

According to Encyclopaedia Britannica (Coyle, n.d.), there are several purposes of imprisonment: to discourage people from committing crimes-including those who have been released from the prison, to serve as punishment for or to obtain retaliation from people who have done serious crimes, to promote personal reformation of people who are imprisoned, and to protect the society from people who are committing crimes. In short, imprisonment aims to prevent, reduce and - ideally, abolish crimes, while at the same time functions to protect the public from 'criminals'.

Michel Foucault, a French philosopher, psychiatrist and historian, however, has an interesting opinion about prisons. In his interview with The New York Times (Droit, 1975), he stated that prison was the ultimate embodiment of discipline; it exercised an entire technique of surveillance, in which individuals were controlled and identified while their movements, activities, and effectiveness were regulated.

Based on these concepts, it can be concluded that the imprisonment, which befall most writers, is meant to take them away from the society and then keep them under surveillance. Imprisonment aims to eradicate crimes and the only crime committed by these writers is writing. So, in this case, the writers are the criminals and their books are the crimes. The writers are imprisoned so that they can be controlled and their books can be eradicated.

Pramoedya Ananta Toer-often regarded as the greatest Indonesian writer-was born on 6 February 1925 in a small town called Blora, Central Java, as the eldest of nine siblings (Perlez, 2006). His father was a headmaster in a local nationalist school and his mother helped the family economy by selling rice (Perlez, 2006). After he finished his primary education, he continued to study at the Radio Vocational School in Surabaya, a much bigger city than Blora (Aglionby, 2006). During the Japanese occupation (1942-1945), he worked as stenographer in
Domei, a Japanese news agency where he developed his writing skills (Aglionby, 2006). After Indonesia declared its independence in 1945, he joined a youth militia to support the new nation's struggle against the Dutch colonial army, who still did not want to let the nation go. He resigned from the army once the war against the Dutch was over and became more absorbed in the world of literature (Lane, 2006). Even though he wrote more than 30 novels, he is mostly known by his masterpiece, Buru Quartet novels: Bumi Manusia (This Earth of Mankind), Anak Semua Bangsa (Child of All Nations), Jejak Langkah (Footsteps), and Rumah Kaca (House of Glass). He based the novels on the "life and imagined experiences of Raden Mas Tirto Adhisuryo, a pioneer in Indonesian journalism, literature and national awakening at the beginning of the twentieth century" (Lane, 2006). He passed away in his family home in Jakarta on 30 April 2006 at the age of 81 after a long struggle against the complication of diabetes and heart disease (Perlez, 2006).

Pram - the name which he preferred to be addressed with - had been imprisoned for three times in his life. The first imprisonment, lasted for 3 years, was administered by the Dutch colonial government due to his involvement in the resistance army (Perlez, 2006). About 10 years later, in 1960, he was imprisoned for the second time by Indonesia's first government after its independence because he wrote articles, that were later published into a book entitled Hoakiau, to oppose the new government regulation that discriminated the Chinese minority in Indonesia (Kurniawan, 2009). He was released after 1 year, only to be imprisoned for the third time 5 years later. This longest one, taking 14 years of his life, came from Indonesia's New Order regime (Kurniawan, 2009). After Indonesia's first president, who always tended to be more socialist than democratic, was overthrown during the coup d'état, the New Regime tried to clean the nation from anyone or anything socialist-related. Pram and his involvement with Lembaga Kebudayaan Rakyat (People's Cultural Institution) - usually abbreviated to Lekra, founded on 17 August 1950 by some artists and members of Indonesian Communist Party (Tim Tempo, 2013) _ surely did not miss the cleansing.

Pram started writing professionally in 1947 (Vltchek \& Indira, 2006) at first, in order to survive, as he needed the money to support his younger brothers and sisters. Clearly, people enjoyed his writing considering that he could earn some money from it. Though he had written a good amount of stories, the only book that survived before his first imprisonment was only KranjiBekasi Jatuh, containing only half of the short stories that he wrote because half of them were confiscated by Netherlands Indies Field Security (Kurniawan, 2009). There was no official record found regarding its exact sale numbers, so it is rather impossible to compare its success to his other books, produced while he was imprisoned, from the selling aspect. Yet, considering that the sale number is not the only thing that could determine the success of a book, we can take a look at other aspects.

During his first imprisonment, he managed to smuggle his works out with the help of a Dutch Professor, G.J. Resink (Kurniawan, 2009). These two manuscripts were Perburuan (The Fugitive) and Keluarga Gerilya 
(freely translated as "Guerilla Family" as there is no record of its English translation). Perburuan won the first prize of the 1950 writing competition held by Balai Pustaka (Toer, 1963), a highly respected literary publishing house in Indonesia at that time. Meanwhile, Keluarga Gerilya made its way to the compulsory reading list of middle schools in Malaysia since 1970 though the Malaysian publisher failed to pay the royalty (Razif, 2006). From these facts, it was clear that compared to Kranji-Bekasi Jatuh, Perburuan was more successful in terms of winning a prestigious writing award and Keluarga Gerilya was more successful in terms of cross-nation readership. However, a more distinct comparison can be seen on the success of Bumi Manusia (This Earth of Mankind), the first book in Buru Quartet series, which was written during his third imprisonment. It has been translated into 36 different languages up to year 2006 since it was first published in 1980 (Vltchek \& Indira, 2006). Clearly, it is not difficult to see which book turned out to be much more successful in the international world.

The comparison above is not meant to compare the quality or content of Pram's works, as every piece has its own uniqueness and strong points. It is simply to show that even though Pram's works had been widely acclaimed and published before he was thrown into jail, he got more attentions - international ones, even - when and after he got imprisoned and banned.

Aftercloselyexamining thepurposeofimprisonment and also Pram's success with Bumi Manusia, it is evident that the authority failed to achieve their objective, which was to discourage Pram from committing his 'crimes' so that his 'crimes' would disappear. Despite the fact that he was imprisoned, he was still writing and his books did not wither and die. On the contrary, they flourished. So now, we are left with the question, 'Why?' or 'How?' This is when the paper brings Pierre Bourdieu into the analysis.

A renowned French sociologist, Pierre Bourdieu, believes that one's success - in this case, in producing great literary works - is not detached from the capital one has. The capital here has a broader meaning than just the capital in economic sense, the capital can also take noneconomic forms. Bourdieu extends the concept of capital as stated by Blunden (2004) in his review of Bourdieu's book Distinctions, "Capital is the resource, command of which, enables one to exercise and resist domination in social relations, or putting it another way, to maintain a position in the status hierarchy of society, or putting it objectively, an 'organizing principle"' (para. 8). Before this paper analyze further the capital that Pram had, it is better to understand what capital is about.

Jenkins (1992:85) explained that the capital could be categorized into four forms: economic capital, social capital, cultural capital, and symbolic capital. Economic capital is referring to one's financial power, like how much money or valuables one possesses. Cultural capital (Blunden, 2004, para. 15) is "all those manners which infallibly identify you to others as a person of a culture, popular, avant garde, or legitimate, with a likely trajectory in life (declining or rising), likely to have access to certain circles or not, and with more or less right to have an opinion on political matters or whatever." Thus, one's social origin is highly influencing one's cultural capital
(Blunden, 2004). Education may offer a ladder for social climbers to gain this culture capital though Bourdieu's research (Blunden, 2004, para. 18) finds that "'scholastic' culture can never quite duplicate the ease and depth of the cultural capital acquired by constant exposure at home". Social capital "are 'connections' needed, in particular, to make use of one's cultural or scholastic capital (certificates)" (Blunden, 2004, para. 23). In short, social capital is referring to the people one knows, people that matter. Symbolic capital, according to Jenkins (1992:85), refers to prestige and social honor.

Bourdieu (1986, para. 27) also said, "The different types of capital can be derived from economic capital, but only at the cost of a more or less great effort of transformation, which is needed to produce the type of power effective in the field in question." This means that the capital, though it could be categorized into four different types, is transformable. For example, a man who has a lot of money (economic capital) could afford to have the membership of a prestigious golf-club, which could lead him to get acquainted with high-class figures (social capital). In this case, his economic capital is transformed into social capital. It is important to be aware of the capital's convertibility as most of Pram's capital is transformable.

Based on the definition of economic capital, it might seem that Pram did not have it, considering that he was not born into a wealthy family. All his life, he was practically earning money from his writing, so he did not get his works published due to his ownership of some financial power. He often said that he did not know how to do any other work and that was why he just wrote (Vltchek \& Indira, 2006:113). However, a year after his release in 1979, he joined force with Joesoef Isak, a former journalist for Merdeka newspaper who had been imprisoned for over a decade before being released, and Hasjim Rachman, who was detained in Buru Island together with him, to form a publishing company named Hasta Mitra (Razif, 2006). At first, Joesoef admitted that the main funding came from Hasjim's own pocket, but then some sympathizing colleagues and friends donated some money to add to the funding they had so that the publishing company could start running (Razif, 2006). Repeating what Bourdieu said about capital that was convertible, here Pram managed to obtain the economic capital due to his social capital, which was his relationship with Hasjim Rachman, Joesoef Isak and those sympathizing people.

In term of culture, Pram clearly possessed a very good capital. As mentioned before, his father was a headmaster of a nationalist school. Without doubt, his father was a highly educated man to be able to hold such position. Moreover, it was really rare to have an Indonesian who had the consciousness for nationalism, especially at that time. Even Sumpah Pemuda (The Youth Pledge), that has always been addressed as the first nationalist movement in Indonesia did not happen until 1928, three years after Pram was born. Pram even said in the beginning of his interview, "I was raised in a left-wing nationalist family that opposed the colonial system," (Vltchek \& Indira, 2006:51). His mother, who seemed to be less educated than his father, turned out to be a woman with a sophisticated mind. A woman, during the colonization period in particular, would not have said to her son that he was "a person with 
'all-round' talents... not someone's slave, but not a slave driver, either" (GoGwilt, 2006, para. 9). It is obvious that his parents were no ordinary people, they were two of the very few Indonesians who were totally aware of human rights and that colonization violated those rights. Pram might not have been born into monetary wealth, but he was definitely born into intellectual wealth.

Pram's strong cultural capital even seemed to outshine his education, which was not as impressive as his works. Although he was fortunate enough to have been schooled at all, he was never educated in prestigious schools. That was why, in a later stage of his life, when a professor from Leiden University invited him to lecture at Res Publica University, Netherlands, Pram responded, "How can I teach at university if I never finished junior high school," (Vltchek \& Indira, 2006:111-112). This shows that his achievement as a writer, shaped by his cultural capital, enabled him to permeate the world of academia, which would then further support his writing reputation.

In addition to such privilege, he was also exposed to the world of literature from a rather young age because his father was apparently a writer (Toer, 1981:18). This early exposure was most probably what drove him to work in journalism at the first place during the Japanese occupation. Yet, being raised in a nationalist family, he could not resist joining the resistance army when his nation was fighting for its independence. His nationalistic action, though bringing forth his first imprisonment by the Dutch colonial government, had won him the attention of the nation's leaders, including Indonesia's first president, Soekarno. Again, thanks to his cultural capital, he could get acquainted to the people in 'high places', to the people that mattered.

It is not illogical to say that his nationalism, obtained from his cultural capital, had caused his first imprisonment to develop his social capital for it was in prison did he get to be visited by sympathizing intellectuals. One prominent visitor was G.J. Resink, a Dutch professor, writer and historian, who was teaching in the law school of University of Indonesia (Reksodiputro, n.d.). He played a big role in Pram's early literary life by smuggling Perburuan and Keluarga Gerilya out of the prison. He also forwarded Perburuan to H.B. Jassin, a famous Indonesian literary writer and critic who worked at Balai Pustaka (Tempo, 2013), to be included in its prestigious writing competition. Perburuan, as mentioned earlier in this paper, won the first prize and was published in 1950 (Toer, 1963). This achievement made himself a reputable name in Indonesia's literary world.

Once more, his social capital developed as his fame as a writer escalated after his second imprisonment. His commitment in defending human rights led him to write articles on Berita Minggu (Sunday News) to oppose the president's regulation PP $10 / 60$, a racist regulation that dispelled the Chinese minority from their economic ventures in Indonesia (Kurniawan, 2009). Upon his arrest, Hoakiau, as the compilation of these articles was entitled, then drew the attentions from the neighboring countries. The book was translated and published in Cambodian, Burmese and Chinese (Abidien \& Prabandari, 1998, para. 8). Pram's reputation as a writer became stronger, not just nationally, but also internationally.

Ultimately, his third imprisonment boosted his social capital that he was forged into an international literary legend. In 1965, Indonesia experienced a big political change. Soekarno was toppled by the rightwing military that put Soeharto on the presidential seat. Despite the fact that Pram was imprisoned by Soekarno for Hoakiau, he was still considered Soekarno's supporter due to his left-wing ideology. Afraid that Pram could indoctrinate the public through his writing, the Soeharto Regime arrested him without any trials, seized his property, banned his books and put him into exile for 14 years in Buru Island, where the prisoners were tortured and forced to hard labor (Vltchek \& Indira, 2006:7277). By the time he was arrested, Pram had already had a strong network within the international literary world, so this imprisonment only strengthened and widened that network for most writers support the right to write, the right Pram was denied from.

In the first half period of his imprisonment, Pram was not given any access to paper or pen, let alone a typewriter. Yet, he was not only a writer, he was also a storyteller. At night, he would orally tell his fellow inmates the story about a young Javanese journalist named Minke, his fateful meeting with the charismatic Nyai Ontosoroh, his romance with her daughter, Annelies and all of his revolutionary life struggles set during the turning of 20th century Indonesia. His tales, which later on were published and known as Buru Quartet novels, had firstly become the inmates' hopes and moral support (Ali, 2006, para. 5). Even in prison, he seemed to hold some social importance, some social honor, that could link back to Bourdieu's symbolic capital. The prisoners would not have listened to his stories, or even "shoulder[ed] up his labor duties so he can put his words onto paper" (Culture Shock, PBS Online, n.d., para. 2) when he was finally allowed to write in the later years of his imprisonment, if he was not seen prestigious.

During his Buru imprisonment, Pram was visited by international visitors and also some prominent national figures, one of which was General Soemitro. He came in 1973, bearing order from President Soeharto to officially inform Pram that starting from that moment on, he was allowed to write (Vltchek \& Indira, 2006:80). This lift of writing restriction was the result of the international pressure that was constantly demanding Indonesian government to let him write, as what Pram (Vltchek \& Indira, 2006:80) admitted in his interview, "I was allowed to write because of the pressure from outside." He always believed that it was the monitor from the international world that saved him during his time in Buru (Vltchek \& Indira, 2006:117). He said in his interview, “I wasn't tortured, probably because my whereabouts were monitored by the outside world," (Vltchek \& Indira, 2006:78). To sum up, it was his international network that enabled him to continue writing from his exile.

However, the journey of Buru Quartet novels was not that smooth. As predicted, the authorities confiscated all of his works. Fortunately, he had foreseen this and made several copies of his manuscripts and got them smuggled out of Buru Island, with the help of some boatmen and priests that forwarded them to Europe, United States or 
Australia (Culture Shock, PBS Online, n.d., para. 2). Only after his release was Pram able to compile his manuscripts and prepare his first book of the Buru Quartet, Bumi Manusia, to be published in 1980. According to Hasta Mitra's main editor, Isak (1999, para 13), in Fordham University symposium, "Over night Pramoedya became a popular sensation. His books were sought after by all sections of society: ordinary people, students, journalists, housewives and even officials, although the latter often searched for his books secretly."

Bumi Manusia was reprinted six times and it was during the last printing that the Attorney General put a ban on it together with its sequel, Anak Semua Bangsa, the second book of Buru Quartet (Isak, 1999, para. 15). Again, the censorship failed to silence Pram's works. The ban, of course, simply created a huge black market for both books, just like what Isak (1999, para. 15) confirmed. In the same symposium, Isak (1999, para 3) also admitted that the press coverage, either domestic or foreign, about the bannings, interrogations and other intimidation suffered by Pram and Hasta Mitra became excellent advertisements, "very effective free publicity which has helped greatly the sale and distribution of Pramoedya's books."

From what the publisher said about the good effect that Pram's first two books of Buru Quartet received from the censorship, it is clear that the authority's effort to silence him totally failed. Disregarding that Pram's works were of great literary quality, this free publicity was received mainly to the connections that he had. The strong network that showered him with international attention, one that had helped him survive the persecution in Buru Island, was still as strong. The world was watching him, people wanted to know what happened to him after he was released and the readers were waiting to read his works. This made any news about him to be sought after by the press. If he had not been well-respected in the literary world and the international world had not cared about him, the press would not have bothered to report the bannings and the intimidations that Pram and Hasta Mitra suffered from. Thus, his social capital proved itself to be stronger than imprisonment and censorship time after time.

Not too long before the ban was issued, however, Max Lane, a staff of the Australian Embassy in Jakarta, had offered to translate Bumi Manusia into English (Fawzi \& Bahrawi, n.d., para. 6-7). When he was found translating this book, he was dismissed from the consulate and deported home (Aglionby, 2006). He continued the translation in his home country and managed to get it published by one of the biggest publishing houses, Penguin Books (Lane, 2005). Again and again, the authority's effort to destroy Pram's books did not succeed. On the contrary, it only 'promoted' them to be widely published throughout the world.

\section{CONCLUSION}

Based on the discussions, this paper concluded that Pram's triumph over imprisonment and censorship cannot be separated from the capital that he obviously possessed, just like what Bourdieu believes. The international success of Buru Quartet novels is not only the result of their great literary quality, but also the result of their writer's cultural and symbolic privilege as well as his strong connections with the people that matter. Pram's capital has proven its superiority by transforming imprisonment and censorship into a boosting power in publishing his books worldwide. This eminent success is reflected on the 36 languages that the books have been translated into. It was a much higher number than the one he had ever achieved before he was persecuted. Does it not make us wonder-disregarding the great quality of his works - if his Buru Quartet novels would have achieved the same fame and number had Pram not been imprisoned and banned?

To end this paper, allow the writer to quote $\mathrm{Mr}$. Pram's favorite saying (Vltchek \& Indira, 2006:109), "My writing was my answer to them: by continuing, I showed that my culture was superior." Pram has repeatedly proven that his culture, embodied in his books, superior as it does not only survive, but also thrives under persecution.

\section{REFERENCES}

Abidien, Z. \& Prabandari, P.D. (1998). Pram dan Larangan Buku-Bukunya. Tempo 6 Oct, 1998. Retrieved from https://sites.google.com/site/pramoedyasite/ home/berita-dalam-bahasa-indonesia/pram-danlarangan-buku-bukunya

Aglionby, J. (2006, May 3). Pramoedya Ananta Toer: Indonesia's best known novelist, he survived persecution, imprisonment and censorship. The Guardian. Retrieved from http://www.theguardian. com/news/2006/may/03/guardianobituaries. indonesia

Ali, T. (2006, May 2). On the Death of Pramoedya Ananta Toer. Retrieved from http://www.counterpunch. org/2006/05/02/on-the-death-of-pramoedyaananta-toer/

Blunden, A. (2004). Bourdieu on Status, Class, and Culture. Andy Blunden's Homepage. Retrieved from http://home.mira.net/ andy/works/bourdieureview.htm

Bourdieu, P. (1986). The Forms of Capital. (R. Nice, Trans.). Marxists Internet Archive. Retrieved from http://www.marxists.org/reference/subject/ philosophy/works/fr/bourdieu.htm (Original work published 1979)

Coyle, A.G. (n.d.). Prison. Encyclopcedia Britannica Online. Retrieved from http://www.britannica. com/EBchecked/topic/477205/prison

Culture Shock, PBS Online. (n.d.). Pramoedya Ananta Toer's Buru Quartet 1979. Retrieved from http:// www.pbs.org/wgbh/cultureshock/flashpoints/ literature/pramoedya.html

Droit, R. (1975, August 5). Michel Foucault, on the Role of Prisons. The New York Times on the Web. Retrieved from http://www.nytimes.com/books/00/12/17/ specials/foucault-prisons.html

Fawzi, F. \& Bahrawi, N. (n.d). An interview with Max Lane: On the politics of translation. Asymptote Journal. Retrieved from http://www.asymptotejournal. com/article.php?cat=Interview \&id=9\&curr index $=12 \&$ curPage $=$ Interview

GoGwilt, C. (2006). Writing to the World. Inside Indonesia, 88. Retrieved from http://www.insideindonesia. 
org/feature-editions/writing-to-the-world

Isak, J. (1999, April 24). The shaping of The Mute's Soliloquy: part 1. Prampage. Retrieved from https://sites.google.com/site/pramoedyasite/home/ concerning-pram/the-shaping-of-the-mute-ssoliloquy-part-1

Jenkins, R. (1992). Pierre Bourdieu. Revised Ed. New York: Routledge.

Kurniawan, E. (2009, April 20). Buku, Perang, dan Penjara. Blog Indonesia Buku. Retrieved from http://suplemenibuku.blogspot.co.uk/2009/04/ buku-perang-dan-penjara.html

Lane, M. (2005, April 20). Joesoef Isak wins PEN Australia award. Green Left Weekly. Retrieved from https:// www.greenleft.org.au/node/32709

Lane, M. (2006). Pramoedya Ananta Toer. LINKS International Journal of Socialist Renewal, 29. Retrieved from http://links.org.au/node/223

Perlez, J. (2006, May 1). Pramoedya Ananta Toer, 81, Indonesian Novelist, Dies. The New York Times on the Web. Retrieved from http://www.nytimes. com/2006/05/01/books/01 prem.html? rr=1\&ei=50 $70 \&$ en $=\mathrm{d} 4 \mathrm{a} 8 \mathrm{~b} 0 \mathrm{~b} 47 \mathrm{a} 30189 \mathrm{e} \& \mathrm{ex}=114 \overline{7} 200 \& \mathrm{emc}=$ eta1\&pagewanted $=$ print \&

Razif. (2006). Hasta Mitra Bertarung Melawan Pembodohan. Media Kerja Budaya, 6, 19-22.

Reksodiputro, M. (n.d.). Prof. G.J. Resink. Liber Amicorum Prof Mr Djokosetono. Retrieved from http://www. amicorumdjokosoetono.com/index.php/artikeltentang-rekan-sejawat-prof-djokosoetono/19-profg-j-resink

Tempo. (2013, March 30). Mengenang Balai Pustaka. Retrieved from http://www.tempo.co/read/ kolom/2013/03/30/682/Mengenang-Balai-Pustaka

Tim Tempo. (2013, September 30). Bila Lekra Memaknai Rakyat. Retrieved from http://www.tempo.co/ $\mathrm{read} /$ news/2013/09/30/173517705/Bila-LekraMemaknai-Rakyat

Toer, P.A. (1963, November 10). Pramoedya Ananta Toer Menjawab (I). Lembaran Kebudayaan "Lentera", Bintang Timur.

Toer, P. A. (1981, July 24). Saya Menarik Diri. Optimis, $18-20$.

Vltchek, A. \& Indira, R. (2006). Exile: Pramoedya Ananta Toer in Conversation with Andre Vltchek and Rossie Indira. Chicago: Haymarket Books. 